\title{
Technologia wykonania konstrukcji osłony odzawałowej obudowy kopalnianej - przygotowanie do spawania
}

\author{
A technology of making a construction \\ of anti-breaking down mining support \\ - preparation to a welding process
}

\section{Streszczenie}

Omówiono zagadnienia dotyczące produkcji obudowy górniczej, w tym oznaczanie i identyfikację materiałów, przygotowanie detali do spawania, składanie i sczepianie oraz kontrolę sczepiania. Przedstawiono wymagania dotyczące jakości powierzchni po cięciu termicznym oraz zasady wykonywania spoin sczepnych czołowych i pachwinowych. Omówiono sczepianie za pomocą płytek dobiegowych i wybiegowych oraz za pomocą klamer sczepnych (od strony lica i od strony grani spoiny). Podano wymagania dotyczące szerokości szczelin w złączach po sczepianiu. Przedstawiono także zasady prowadzenia kontroli detali po sczepianiu.

Słowa kluczowe: spawanie, osłona odzawałowa

\section{Wstęp}

Przedstawiono wytyczne prowadzenia procesu wytwórczego konstrukcji spawanej obudowy górniczej ze szczególnym uwzględnieniem procesów spawalniczych takich jak:

- cięcie termiczne detali,

- ukosowanie za pomocą cięcia termicznego,

- prowadzenia procesów sczepiania, montażu i spawania konstrukcji,

- prowadzenia badań nieniszczących spoin.

Zakres zagadnienia obejmuje opis procesu wytwórczego - od magazynowania materiałów spawalniczych,

\section{Abstract}

Issues referring to the production of a mining support such as: determining and identifying materials, preparing details to welding, assembling, positioning and controlling were described. All the requirements which refer to the quality of a surface after a thermal cutting and the rules to make positional welds both butt joints and fillet welds were shown. Positioning by run-on and run-off plates and bracing clamps (from the face and the back of weld) was given. Requirements relating to the width of gaps in the joints after positioning were provided. Moreover, the rules of controlling the details after positioning were given.

Key words: welding, anti-braking down mining support

oznaczania i identyfikacji materiałów podstawowych, przez prawidłowe przygotowanie detali do spawania, składanie i sczepianie poszczególnych elementów wg kart technologicznych montażu, podgrzewanie przed spawaniem, spawanie wg Instrukcji Technologicznych Spawania (WPS) i planów spawania, prowadzenie badań nieniszczących oraz w przypadku wykrytych niezgodności wykonywanie napraw.

W publikacji omówiono wymagania dotyczące produkcji konstrukcji spawanych, w tym oznaczanie i identyfikację materiałów, przygotowanie detali do spawania, składanie i sczepianie oraz kontrolę sczepiania $[1 \div 19]$.

Dr hab. inż. Jacek Słania, prof. PCz - Politechnika Częstochowska, mgr inż. Henryk Marcinkiewicz, mgr inż. Mariusz Kiełbik - FMG Pioma S.A. Grupa Famur. 


\section{Wymagania dotyczące produkcji konstrukcji spawanych}

\section{Oznaczenie i identyfikacja materiałów}

Podczas wykonywania konstrukcji spawanych należy ustalić odpowiednią identyfikowalność i system potwierdzania tożsamości wszystkich materiałów konstrukcyjnych używanych w trakcie produkcji. System ten ma zapewnić, że tylko skontrolowane materiały właściwego gatunku mogą być przeznaczone do produkcji oraz umożliwić w czasie produkcji śledzenie i identyfikowalność materiałów użytych do produkcji, zgodnie z rysunkami i listami materiałowymi (np. wszystkie detale oznakowane markerem na powierzchni), oraz archiwizację dokumentacji.

\section{Przygotowanie detali do spawania}

Pierwszą fazą produkcji jest przygotowanie poszczególnych detali. Z uwagi na to, iż konstrukcja osłony to konstrukcja spawana $z$ blach, podstawowym procesem wykonania detali jest cięcie termiczne z blach kształtów zewnętrznych i otworów poszczególnych detali na automatach do cięcia.

Na rysunkach 1 i 2 pokazano tężniki główne i żebra konstrukcji osłony po operacji cięcia termicznego. Widoczne są wyraźnie wypływki stopionego metalu, zendra oraz żużle po cięciu gazowym.

Następnym etapem procesu technologicznego jest przygotowanie krawędzi do wykonania spoin czołowych - ukosowanie (fazowanie) brzegów detali zgodnie z rysunkami konstrukcyjnymi. Operacje ukosowania wykonuje się przez cięcie termiczne (najczęściej cięcie gazem ziemnym), bądź obróbkę mechaniczną w zależności

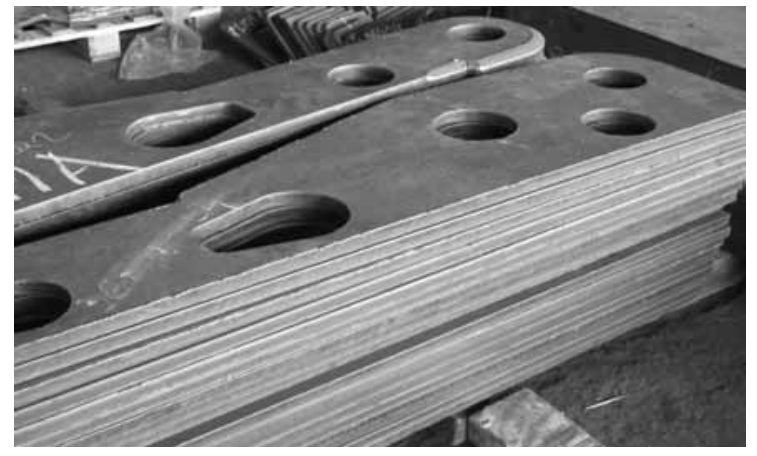

Rys. 1. Tężniki główne po operacji cięcia termicznego

Fig. 1. The main braces after a thermal cutting

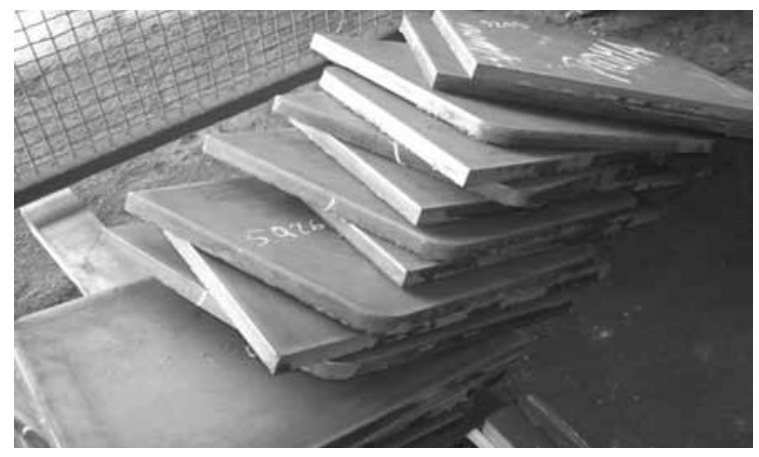

Rys. 2. Żebra po operacji cięcia termicznego

Fig. 2. Ribs after a thermal cutting process od złożoności kształtu detalu lub jego wielkości. Na rysunkach 3 i 4 pokazano wykonane cięciem termicznym fazowania pod spoiny czołowe na tężnikach głównych i nakładkach. W obrębie sfazowania widoczne są wypływki stopionego metalu, zendra oraz żużle po cięciu termicznym.

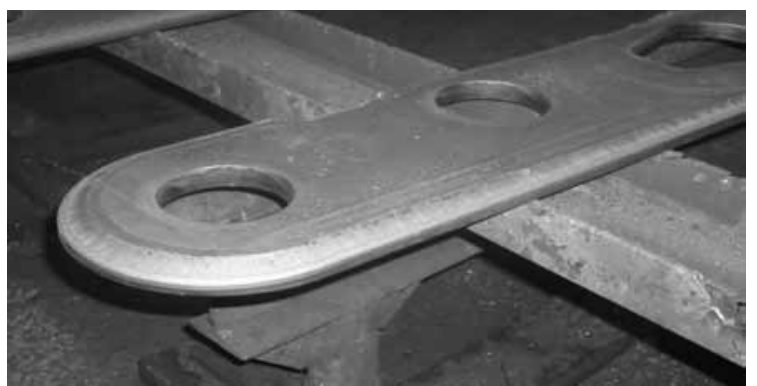

Rys. 3. Tężniki główne po operacji ukosowania termicznego Fig. 3. The main braces after a thermal beveling process

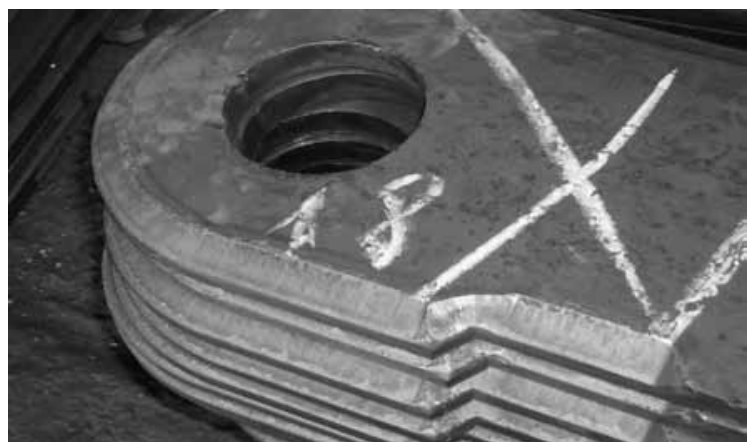

Rys. 4. Nakładki tężników po operacji ukosowania termicznego

Fig. 4. Butt straps of braces after a thermal beveling process

Brzegi elementów do wykonania spoin należy ukosować za pomocą cięcia termicznego lub obróbki mechanicznej zgodnie z kształtem podanym w dokumentacji konstrukcyjnej. Powierzchnie blach i kształtowników przeznaczone do cięcia gazowego powinny być suche, czyste i bez zendry. Przed rozpoczęciem cięcia termicznego blachy powinny mieć co najmniej temperaturę otoczenia panującą na hali, w której będzie prowadzony proces.

Powierzchnie po cięciu należy oszlifować do „białego metalu" w celu usunięcia tlenków powstałych przy cięciu i żużla. Wszystkie wióry i opiłki powstałe po obróbce mechanicznej muszą być usunięte z konstrukcji. Powierzchnia po cięciu i ukosowaniu brzegów pod spoinę powinna być wolna od rdzy, wżerów, nadpaleń oraz wierzchołków (ząbków). Ząbki, których wysokość przekracza $0,5 \mathrm{~mm}$, należy szlifować. Wżery o głębokości $\leq 1,5 \mathrm{~mm}$ należy usunąć przez szlifowanie, natomiast wżery, których głębokość przekracza 1,5 mm, napawać. W przypadku operacji napawania należy po oszlifowaniu przeprowadzić badanie napawanego miejsca metodą magnetyczno-proszkową na obecność przyklejeń i pęknięć.

Po operacji cięcia (kształtu i faz) detale poddawane są szlifowaniu wykańczającemu w celu usunięcia zendry, wypływek stopionego metalu i żużli po cięciu zarówno na powierzchniach płaskich, jak i ukosowanych.

Na rysunkach 5 i 6 pokazano oszlifowane wykańczająco tężniki główne osłony. Fazy pod spoiny szlifowane są zwykle do „białego metalu” w celu uniknięcia ewentualnych niezgodności spawalniczych w późniejszych fazach produkcji. 


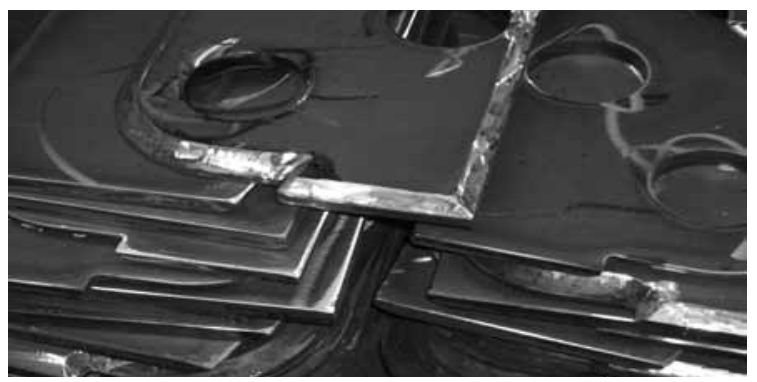

Rys. 5. Tężniki po operacji szlifowania

Fig. 5. Braces after a grinding process

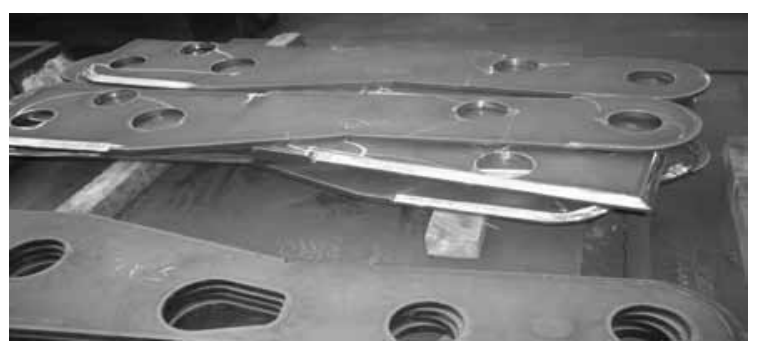

Rys. 6. Tężniki po operacji szlifowania

Fig. 6. Braces after a grinding process

Cięcie termiczne gabarytów detali oraz ukosowanie do wykonania spoin powinno odbywać się zgodnie z technologicznymi kartami rozkroju.

Kąty ukosowania dla spoin czołowych powinny wynosić: - przy spoinach $1 / 2 \mathrm{~V}$ kąt ukosowania $45 \div 50^{\circ}$; maks. $55^{\circ}$;

- przy spoinach $\vee$ kąt ukosowania $50 \div 60^{\circ}$.

W przypadku spoin czołowych bez pełnego przetopu fazy należy wykonać o min. $2 \mathrm{~mm}$ większe od zakładanych w dokumentacji, aby zapewnić, że grubości spoin podane na rysunku zostaną dotrzymane.

Tak przygotowane detale poddaje się operacji prostowania. Prostowanie wykonuje się na prasach hydraulicznych o nacisku 100 lub 400 ton w zależności od grubości blach z jakich wykonano poszczególne detale.

Po prostowaniu wszystkie detale przed przekazaniem do montażu i ewentualnej obróbki wiórowej poddawane są śrutowaniu w komorze śrutowniczej. Śrutowanie wykonuje się w celu dokładnego oczyszczenia detali z rdzy, pozostałej zendry, odtłuszczenia i usunięcia pozostałych zanieczyszczeń mogących mieć niekorzystny wpływ na niezgodności spawalnicze.

Detale bardziej złożone technologicznie (typu tuleje, uchwyty gwintowane czy zawiesia) wymagające obróbki wiórowej przekazywane są na wydział mechaniczny w celu koniecznej obróbki mechanicznej, zaś detale z blach przekazywane są na wydział montażowy.

\section{Składanie i sczepianie}

Do składania i sczepiania można stosować tylko detale zakwalifikowane przez kontrolę techniczną jako dobre zgodne z rysunkiem konstrukcyjnym, tzn. takie, których wymiary mieszczą się w granicy tolerancji, a powierzchnie i krawędzie są wolne od zanieczyszczeń i uszkodzeń. Podczas sczepiania materiałów o różnej wytrzymałości spoiwo należy dobierać do detalu wykonanego ze stali o mniejszej wytrzymałości.

Spoiny sczepne powinny być wykonane w ilości niezbędnej do prawidłowego ustalenia łączonych części podczas spawania oraz bezpiecznego transportu międzystanowiskowego i obracania elementów. Spoina sczepna powinna charakteryzować się dobrą jakością oraz głębokim wtopieniem w materiał.

Podczas układania spoin sczepnych należy przyjąć następujące zasady:

$$
t=(20 \div 30) g \leq 450 \mathrm{~mm}
$$

gdzie: $\mathrm{t}$ - podziałka spoin sczepnych, g - grubość cieńszego elementu.

Wielkość i długość spoin sczepnych w zależności od grubości materiału przedstawiono w tablicy I.

Tablica I. Wielkość i długość spoin sczepnych w zależności od grubości materiału

Table I. The size and length of positional welds depending on the thickness of a material

\begin{tabular}{|c|c|c|}
\hline $\begin{array}{c}\text { Grubość blachy } \\
\mathrm{g}, \mathrm{mm}\end{array}$ & $\begin{array}{c}\text { Grubość } \\
\text { spoiny sczepnej } \\
\mathrm{a}_{\mathrm{s}}, \mathrm{mm}\end{array}$ & $\begin{array}{c}\text { Długość spoiny } \\
\text { sczepnej I, mm }\end{array}$ \\
\hline$<15$ & 3 & $20 \div 30$ \\
\hline $15 \div 30$ & 4 & $30 \div 40$ \\
\hline$>30$ & 5 & $40 \div 60$ \\
\hline
\end{tabular}

Wszystkie spoiny sczepne muszą być tak wykonane, aby mogły być integralną częścią przyszłej spoiny, nie powinny mieć pęknięć, kraterów, przyklejeń i porów. Zalecane jest, aby spoiny sczepne wykonywać w pozycji podolnej (PA) oraz nabocznej (PB).

Przy wykonywaniu krótkich spoin sczepnych, napoin oraz podczas zajarzania łuku, ze względu na bardzo wysoką lokalną temperaturę i małą energię liniową oraz zwiększoną szybkość chłodzenia w strefie wpływu ciepła (SWC) mogą powstać pęknięcia. Pęknięcia te mogą być inicjatorami rozprzestrzeniania się kruchego pękania. Przy grubości powyżej 20 mm niezależnie od sposobu przygotowania brzegów spoiny uzyskuje się maksymalną szybkość chłodzenia. Bardzo duże szybkości chłodzenia powodują krótkie spoiny sczepne i napoiny o długości poniżej $30 \mathrm{~mm}$, przy czym im krótsza spoina tym intensywniejsze chłodzenie SWC [19].

Zaleca się wykonywanie spoin sczepnych o grubości

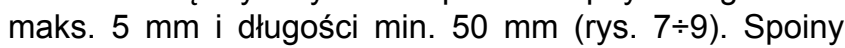
sczepne należy układać od środka elementu sczepnego w kierunku jego brzegów jak pokazano na rysunku 10.

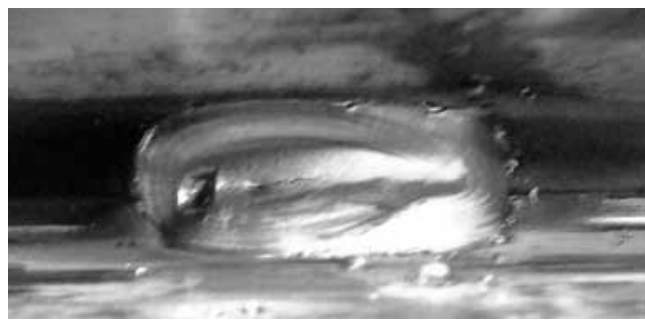

Rys. 7. Spoina sczepna nieprawidłowa - zbyt krótka, poniżej $30 \mathrm{~mm}$ o nadmiernej grubości $z$ kraterem i pęknięciem

Fig. 7. An improper positional weld - too short, less than $30 \mathrm{~mm}$ with an excessive thickness with a crater and a fracture 


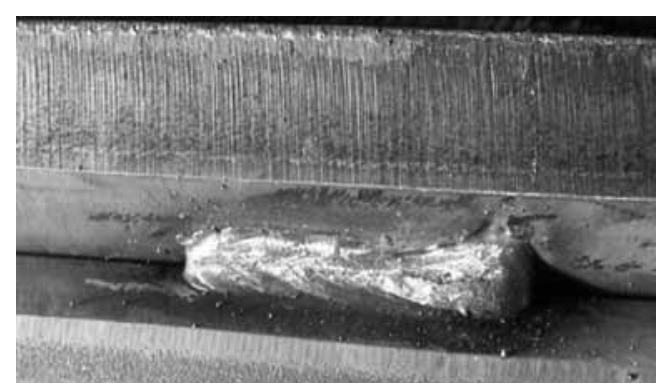

Rys. 8. Spoina sczepna prawidłowa o długości min. $50 \mathrm{~mm}$ Fig. 8. A proper positional weld, minimum $50 \mathrm{~mm}$ long

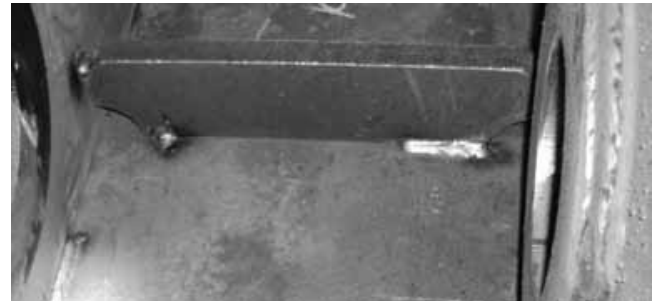

Rys. 9. Spoiny sczepne - lewa strona nieprawidłowa, prawa strona prawidłowa (dł. $\min .50 \mathrm{~mm}$ )

Fig. 9. Positional welds - left side improper, right side - proper (minimum $50 \mathrm{~mm}$ long)

W przypadku układania spoin sczepnych z dwóch stron elementu należy układać spoiny na przemian z dwóch stron od środka w kierunku jego końców (rys. 11). Spoiny sczepne wykonywać należy w miejscach łatwo dostępnych do wyszlifowania w przypadku ich pęknięcia. Powinny one mieć wymiary:

\section{- spoiny sczepne czołowe}

Wymiary spoin sczepnych podano w tablicy II.

Kolejność wykonywania spoin sczepnych czołowych przedstawiono na rysunku 10.

Tablica II. Wymiary spoin sczepnych czołowych

Table II. Measurements of positional butt joint welds

\begin{tabular}{|c|c|c|}
\hline $\begin{array}{c}\text { Grubość blach } \\
\mathrm{g}, \mathrm{mm}\end{array}$ & $\begin{array}{c}\text { Grubość } \\
\text { spoiny sczepnej } \\
\mathrm{a}_{\mathrm{s}}, \mathrm{mm}\end{array}$ & $\begin{array}{c}\text { Długość } \\
\text { spoiny sczepnej } \\
\text { I, mm }\end{array}$ \\
\hline $4 \div 12$ & $3 \div 4$ & $30 \div 40$ \\
\hline powyżej 12 & $0,33 \mathrm{~g}$ (maks. 6) & $40 \div 60$ \\
\hline
\end{tabular}
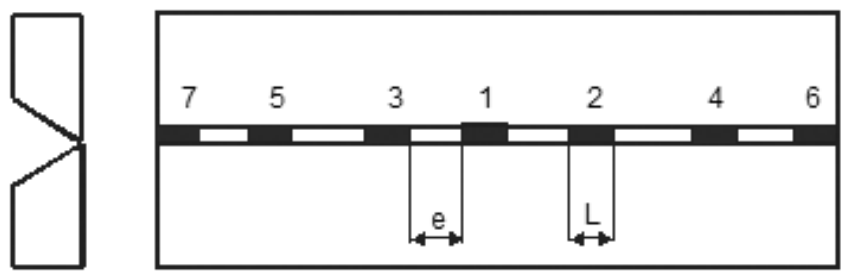

Rys. 10. Kolejność wykonania spoin sczepnych - czołowych: $\mathrm{L}$ - długość spoin sczepnych, mm; e - odstęp między spoinami sczepnymi $(20 \div 30) g$; g - grubość łączonych elementów, mm - max. $450 \mathrm{~mm}$ (tabl. I)

Fig. 10. Sequence of positional butt joints welding: $L-$ positional weld length, mm; e - distance between positional welds $(20 \div 30) \mathrm{g}$, $\mathrm{g}$ - the thickness of welded plates, $\mathrm{mm}$; max. $450 \mathrm{~mm}$ (tab. I)

\section{- spoiny sczepne pachwinowe}

Wymiary spoin sczepnych pachwinowych przedstawiono w tablicy III.

Kolejność wykonywania spoin czepnych pachwinowych przedstawiono na rysunku 11. Przy spoinach przerywanych należy wykonać spoiny sczepne w miejscach występowania spoin.

Tablica III. Wymiary spoin sczepnych pachwinowych Table III. Measurements of positional fillet welds

\begin{tabular}{|c|c|c|}
\hline $\begin{array}{c}\text { Grubość } \\
\text { nominalna spoiny } \\
\text { pachwinowej } \\
\text { a, mm }\end{array}$ & $\begin{array}{c}\text { Grubość } \\
\text { spoiny sczepnej } \\
\mathrm{a}_{\mathrm{s}}, \mathrm{mm}\end{array}$ & $\begin{array}{c}\text { Długość } \\
\text { spoiny sczepnej } \\
\text { I, mm }\end{array}$ \\
\hline $2 \div 6$ & $2 \div 3$ & $20 \div 30$ \\
\hline $6 \div 10$ & $3 \div 4$ & $30 \div 40$ \\
\hline powyżej 10 & $0,4 \mathrm{~g}$ (maks. 6) & $40 \div 60$ \\
\hline
\end{tabular}
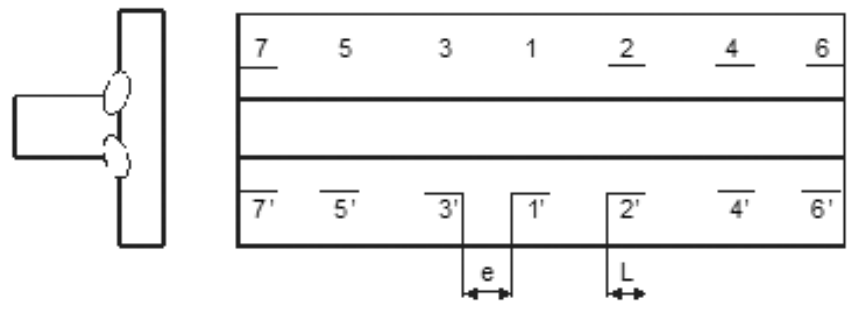

Rys. 11. Kolejność wykonania spoin sczepnych pachwinowych

Fig. 11. An order of making positional fillet welds.

\section{Sczepianie za pomocą płytek wybiegowych i dobiegowych}

Przy wykonywaniu spoin jednostronnych z pełnym przetopem należy stosować sczepianie za pomocą specjalnych klamer. W celu zabezpieczenia właściwej jakości spoin, na jej końcach należy stosować do sczepiania płytki wybiegowe i dobiegowe. Po wykonaniu spoiny sczepne mocujące klamry należy zeszlifować. Spoiny te powinny być wykonane w miejscach umożliwiających ich całkowite wycięcie w przypadku wadliwego wykonania lub pęknięcia pod wpływem naprężeń.

Na rysunku 12 przedstawiono sposób sczepiania płytek dobiegowych i wybiegowych do wykonania spoin jednostronnych z pełnym przetopem.

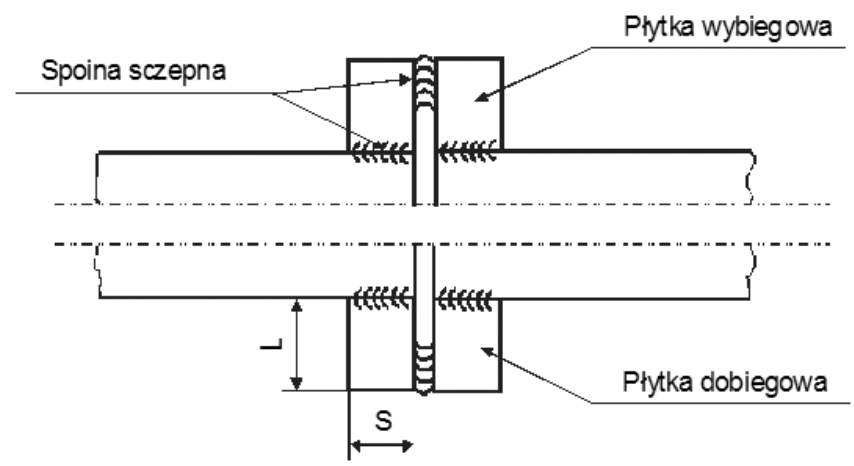

Rys. 12. Sposób sczepiania płytek dobiegowych i wybiegowych dla spoin jednostronnych z pełnym przetopem

Fig. 12. A method of positioning run-on and run-off plates for single - side welds with a complete penetration weld 
W tablicy IV podano wymiary płytek wybiegowych i dobiegowych w zależności od grubości elementów łączonych.

Tablica IV. Wymiary płytek wybiegowych i dobiegowych w zależności od grubości elementów łączonych

Table IV. Measurements of run-on and run-off plates depending on the thickness of joined elements

\begin{tabular}{|c|c|c|}
\hline $\begin{array}{c}\text { Grubość } \\
\text { elementów } \\
\text { łączonych } \\
\mathrm{g}, \mathrm{mm}\end{array}$ & $\begin{array}{c}\text { Długość płytki } \\
\text { L, mm }\end{array}$ & $\begin{array}{c}\text { Szerokość płytki } \\
\text { S, mm }\end{array}$ \\
\hline $2 \div 4$ & 30 & 25 \\
\hline $4 \div 12$ & 40 & 30 \\
\hline powyżej 12 & 50 & 40 \\
\hline
\end{tabular}

Sposób ukosowania (przygotowania) płytek wybiegowych jest identyczny jak w złączu spawanym. Grubość płytek wybiegowych jest taka sama jak grubość materiału spawanego.

\section{Sczepianie za pomocą płytek i klamer}

Na rysunku 13 przedstawiono sposób sczepiania za pomocą klamer oraz płytek dobiegowych i wybiegowych do wykonania spoin jednostronnych z pełnym przetopem.

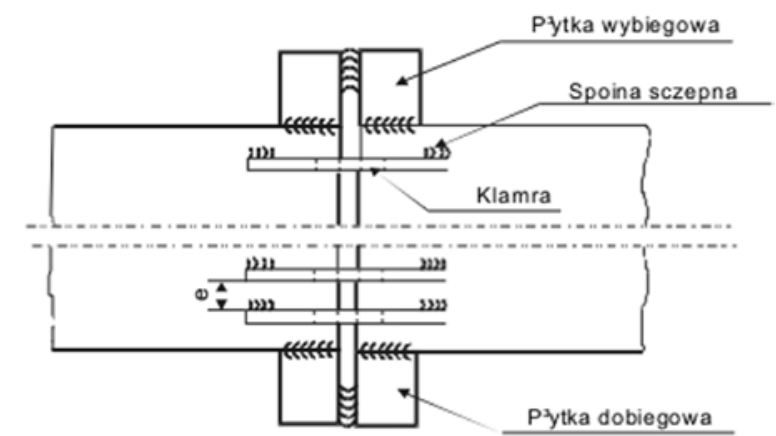

Rys. 13. Sposób sczepiania klamer oraz płytek dobiegowych i wybiegowych dla spoin jednostronnych z pełnym przetopem

Fig. 13. A method of positioning clamps and run-on and run-off plates for single - side welds with a complete penetration weld

\section{Klamry zakładane od strony lica spoiny}

Na rysunku 14 przedstawiono klamrę do sczepiania zakładaną od strony lica spoiny.

Wymiary klamer zakładanych od strony lica spoiny zamieszczono w tablicy $\mathrm{V}$.

Uwaga: Odległość między klamrami powinna wynosić $\mathrm{e}=(40 \div 50) \mathrm{g}$, gdzie g - grubość łączonych elementów.

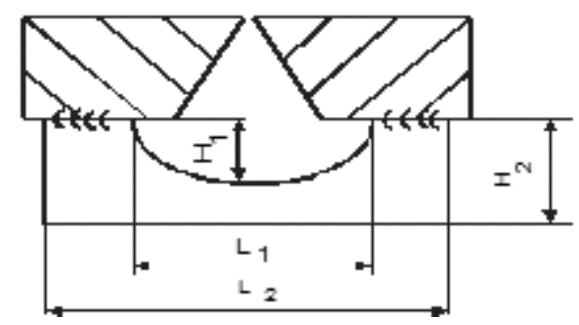

Rys. 14. Szkic klamry zakładanej od strony lica spoiny Fig. 14. A sketch of a clamp installed on the face of weld
Tablica V. Wymiar klamer zakładanych od strony lica spoiny Table V. A measurement of clamps installed on the face of weld

\begin{tabular}{|c|c|c|c|c|c|}
\hline \multirow{2}{*}{$\begin{array}{c}\text { Grubość } \\
\text { łączonych } \\
\text { elementów, } \\
\text { mm }\end{array}$} & \multicolumn{5}{|c|}{ Wymiary klamry } \\
\hline & $\begin{array}{c}\mathrm{L}_{1} \\
\mathrm{~mm}\end{array}$ & $\begin{array}{c}\mathrm{L}_{2,} \\
\mathrm{~mm}\end{array}$ & $\begin{array}{c}\mathrm{H}_{1} \\
\mathrm{~mm}\end{array}$ & $\begin{array}{l}\mathrm{H}_{2} \\
\mathrm{~mm}\end{array}$ & $\begin{array}{c}\text { Grubość } \\
\text { klamry, } \\
\mathrm{mm}\end{array}$ \\
\hline $4 \div 12$ & 25 & 85 & 30 & 60 & 8 \\
\hline powyżej 12 & 40 & 120 & 40 & 80 & 10 \\
\hline
\end{tabular}

\section{Klamry zakładane od strony grani spoiny}

Na rysunku 15 przedstawiono klamrę do sczepiania zakładaną od strony grani spoiny.

Wymiary klamer zakładanych od strony grani spoiny zamieszczono w tablicy VI.

Po wykonaniu spawania klamry należy odszlifować, a miejsca sczepów klamer oszlifować.

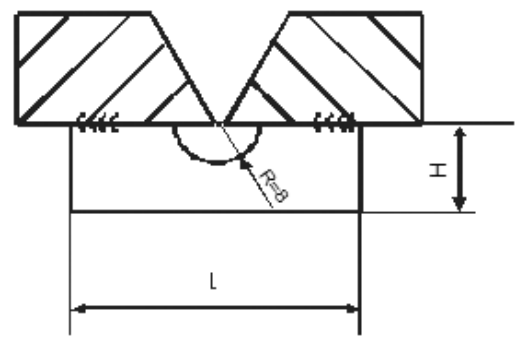

Rys. 15. Szkic klamry zakładanej od strony grani spoiny

Fig. 15. A sketch of a clamp installed on the back of weld

Tablica VI. Wymiary klamer zakładanych od strony grani spoiny Table VI. A measurement of clamps installed on the back of weld

\begin{tabular}{|c|c|c|c|}
\hline \multirow{2}{*}{$\begin{array}{c}\text { Grubość } \\
\text { łączonych } \\
\text { elementów, } \\
\mathrm{mm}\end{array}$} & $\begin{array}{c}\mathrm{L} \\
\mathrm{mm}\end{array}$ & $\begin{array}{c}\mathrm{H} \\
\mathrm{mm}\end{array}$ & $\begin{array}{c}\text { Grubość } \\
\text { klamry, } \\
\mathrm{mm}\end{array}$ \\
\cline { 2 - 4 } & 80 & 40 & 8 \\
\hline powyżej 12 & 100 & 05 & 10 \\
\hline
\end{tabular}

W przypadku powstania wżerów w materiale podstawowym należy je zaspawać i ponownie oszlifować. Miejsca naprawianych ubytków należy sprawdzić metodą magnetyczno-proszkową.

Po wykonaniu spoin sczepnych należy je oczyścić, natomiast te $z$ wadami usunąc przed ułożeniem spoin właściwych za pomocą żłobienia elektropowietrznego lub przez szlifowanie.

Wszystkie spoiny sczepne powinny być wolne od niezgodności typu pęknięcia, pory i kratery.

\section{Szerokość szczelin dopasowania}

Szczelina między detalami przy spoinach pachwinowych może wynosić maks. 1,5 mm (rys. 16a). Przy spoinach czołowych bez przetopu (rys. 16b) maksymalny odstęp między detalami może wynosić $2 \mathrm{~mm}$. Zbyt duży odstęp rowka ma być poprawiony przez napawanie zgodnie z kartą technologiczną naprawy opracowaną przez nadzór spawalniczy. Przy spoinach pachwinowych należy dążyć do osiągnięcia szczeliny $0 \mathrm{~mm}$. Przy szczelinach $1,5 \div 2,0 \mathrm{~mm}$ należy zwiększyć wymiar spoiny pachwinowej (a) o $1 \mathrm{~mm}$. 
a)

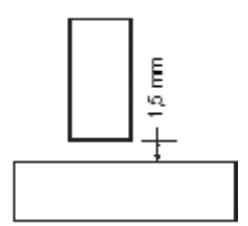

b)

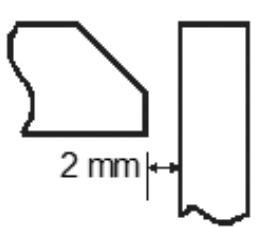

Rys. 16. Szczeliny między detalami: a) przy spoinach pachwinowych, b) przy spoinach czołowych bez pełnego przetopu

Fig. 16. Gaps between details: a) by fillet welds, b) by butt welds with a partial joint penetration

Przy szczelinach większych niż $2 \mathrm{~mm}$, a mniejszych niż $5 \mathrm{~mm}$ należy dokonać naprawy przez napawanie, tak aby wielkość szczeliny mieściła się w prawidłowym zakresie. Grubość strefy napawania dla spoin czołowych nie może przekraczać $5 \mathrm{~mm}$. Jeżeli szczelina jest większa od $5 \mathrm{~mm}$, to naprawy można dokonać jedynie po uzgodnieniu z działem spawalniczym. Stan przygotowania do spawania, tj. kształty geometryczne miejsca spawania

\section{Literatura}

[1] Słania J., Marcinkiewicz H., Kiełbik M.: Plan spawania elementu obudowy kopalnianej - osłony odzawałowej. Przegląd Spawalnictwa 2/2012, s. 6-16.

[2] Słania J., Urbańczyk P.: Technologia oraz plan spawania gazoszczelnych ścian rurowych kotła pyłowego wg normy PN - EN 12952-5. Przegląd Spawalnictwa, 12/2009, s. 19-27.

[3] Słania J.: Technologia spawania płyty wsporczej pojazdu gąsienicowego - dobór parametrów i obliczanie kosztów spawania. Biuletyn Instytutu Spawalnictwa, 2/2010, s. 52-56.

[4] Słania J.: Plan technologiczny spawania płyty gąsienicowej. Przegląd Spawalnictwa, 3/2010, s. 16-25.

[5] Słania J., Kaczor T.: Plan spawania zbiornika ciśnieniowego. Przegląd Spawalnictwa, 4/2010, s. 9-18.

[6] Słania J., Kwiecień L., Jarosiński J.: Plan spawania kotłów płomienicowo-płomieniówkowych. Przegląd Spawalnictwa, 6/2010, s. 32-40.

[7] Słania J., Skóra J.: Plan spawania wymiennika ciepła chłodzonego powietrzem. Przegląd Spawalnictwa 2/2011, s. 16-22.

[8] Słania J.: Plan spawania carg płaszcza pieca obrotowego. Przegląd Spawalnictwa 2/2011, s. 36-41.

[9] Słania J., Wodecki D.: Plan spawania belki poprzecznej dźwigu. Przegląd Spawalnictwa 2/2011, s. 30-35. i stan oczyszczenia powierzchni przed spawaniem powinny być skontrolowane przez spawacza oraz bezpośredni nadzór.

\section{Kontrola dopasowania}

Kontroler prac spawalniczych ma obowiązek prowadzić kontrolę przed przystąpieniem do spawania, w czasie procesu i po jego zakończeniu $[1 \div 3,7 \div 9,13 \div 15,19]$. Obowiązkiem kontrolera jest sprawdzenie wzrokowe i zarejestrowanie dopasowania elementów oraz przygotowanie do spawania, identyfikację wad powierzchniowych, zgodności odstępu rowka i geometrii fazowania z procedurami spawalniczymi (WPS) i tolerancjami ustawienia elementów w linii.

Wszyscy kontrolerzy przeprowadzający kontrolę prac spawalniczych, a zwłaszcza prowadzący badania nieniszczące, muszą posiadać uprawnienia 2 stopnia zgodnie z wymaganiami PN-EN SO 9712, w prowadzonych metodach badań.

[10] Słania J.: Istota planów spawania. Przegląd Spawalnictwa 2/2011, s. 3-9.

[11] Słania J.: Plan spawania napraw bieżących kotłów parowych, wodnych i stałych zbiorników ciśnieniowych. Przegląd Spawalnictwa 2/2011, s. 22-30.

[12] Słania J., Chomiuk S., Dadak R.: Plan spawania dla konstrukcji uzupełniającej - trawresy. Przegląd Spawalnictwa 2/2012, s. 3-6.

[13] Słania J., Fryc H.: Spawanie pojazdów szynowych - plany spawania. Przegląd Spawalnictwa 2/2012, s. 16-20.

[14] Słania J.: Plan spawania stalowej kładki dla pieszych I. Przegląd Spawalnictwa 2/2012, s. 20-24.

[15] Słania J.: Plan spawania stalowej kładki dla pieszych II. Przegląd Spawalnictwa 2/2012, s. 24-26.

[16] Słania J., Urbańczyk P.: Technologia wytwarzania oraz plan kontroli jakości przegrzewacza pary kotła parowego wg PNEN 12952-5. Przegląd Spawalnictwa 5/2012, s. 29-41.

[17] Chromik D., Słania J.: Plan spawania ciśnieniowego zespołu rurowego. Przegląd Spawalnictwa 11/2012, s. 29-32.

[18] Balcerzak M., Słania J.: Spawanie zbiornika bezciśnieniowego do magazynowania oleju opałowego. Przegląd Spawalnictwa 11/2012, s. 33-38.

[19] Słania J.: Usuwanie odkształceń spawalniczych. Przegląd Spawalnictwa 2/2012, s. 24-26. 